\title{
Sciendo
}

\section{Moderating-mediating Effects of Leader Member Exchange, Self-efficacy and Psychological Empowerment on Work Outcomes among Nurses}

\author{
Farzad SATTARI ARDABILI
}

Islamic Azad University, Department of Management, Ardabil Branch, Ardabil, Iran, sattari.farzad@gmail.com; f.sattari@iauardabil.ac.ir

\begin{abstract}
Background: The main effects of leader-member relationship and the quality of supervisor-subordinate relationship are emphasized as main variables that help improve nurses' job satisfaction and reduce exhaustion. The aim of this study is to examine the effects of the emotional intelligence, self-efficacy, and psychological empowerment on psychological exhaustion and job satisfaction of nurses using moderation-mediation effects of leader-member exchange (LMX).

Methods: A cross-sectional design was carried out in three public-sector hospitals in north west of Iran during 2016. A total of 138 self-administered questionnaires were used for analysis. The main hypotheses of this study were analyzed through applying mediation-moderation analysis using PROCESS model.

Results: The results revealed that LMX acted as a mediator between emotional intelligence and job satisfaction through converting its negative effect into positive one. The indirect effect of emotional intelligence on emotional exhaustion through leader-member exchange was strongly negative especially at higher levels of leader-member exchange.

Conclusions: High quality relationships between nurses and their superiors could improve their job outcomes. The negative relationship between emotional intelligence and emotional exhausting was more significant when leader-member exchange was taken into account. High emotional intelligence in nurses has negative effect on job satisfaction but by mediating role of LMX the effect changed to positive. LMX partially mediated the effect of emotional intelligence on job satisfaction, except when self-efficacy values were quite large. Psychological empowerment did not significantly moderate the relationship between emotional intelligence, leader-member exchange, and job outcome. Implications for nursing managers: It is recommended to analyze the quality of leader-member exchange in the hospitals before using them for measurement of nurses' satisfaction and their jobs' outcomes. Managers should also concentrate more on leader-member exchange and try to improve its quality. Future studies are needed to investigate the effects of leader-member exchange quality in longer follow-up periods.
\end{abstract}

Key words: Emotional intelligence, Moderating mediating effect, Leader member Exchange (LMX), Psychological empowerment

\section{Introduction}

It is shown that emotional intelligence has various effects on job outcomes such as job satisfaction (Wen, Huang, \& Hou, 2019). However, based on the idea be- hind the leader-member exchange (LMX), it seems that the impact of emotional intelligence on the consequences of jobs in different occupational groups can change under the influence of some other variables such as the supervisors-subordinates relationship and their obtaining

Received: 5th May 2020; revised: 29th June 2020; accepted: 9th July 2020 
empowerment. Therefore, increasing the managerial and psychological empowerments can improve the quality of the relationship between the nurses or subordinates and their supervisors and hence improve their job satisfaction (Laschinger, Purdy, \& Almost, 2007). The effectiveness of these factors with respect to the culture and perceptions of empowerment in different areas is different in various studies (Al-Maaitah, 2019; Yip, 2004) reveal us its lack of theoretical base. Despite this attention, relatively few previous studies have examined the relationship and mechanism of leader-member exchange among these variables Thus, the main aim of the present study is to assess the mediating role of leader member exchange on the relationship between emotional intelligence and job outcomes including job satisfaction and job exhaustion through evaluating mediation and moderation effects of self-efficacy and psychological empowerment of nurses.

\section{Theory and Hypotheses}

\subsection{Leader-member exchange mediates emotional intelligence, job satisfaction, and emotional exhaustion}

In nursing literature review, Evans and Allen (2002) confirmed the nurses' ability to manage and understand their own emotions and those of their patients is an asset in providing the best possible care, but the potential value of emotional intelligence is an issue that still needs to be searched especially in relationships and work performances. Voitenko (2020) explored the relationship between burnout and emotional intelligence (EI). Emotional exhaustion as the first phase of burnout carries great importance, because it may increase the turnover rates among the employees and may lead to reduced quality of care. Also, the high levels of emotional exhaustion have direct effect on the work outcomes such as job satisfaction (White \& Grayson, 2019); therefore, it seems reasonable to assume that there exists a negative correlation between emotional intelligence and emotional exhaustion. In addition to emotional intelligence and work outcomes, there is another concept which deserves attention such as leader member exchange. Such leadership practices effect on employees' work behavior, burnout and empowerment (Manojlovich, 2005) and relationship between high quality of leader-member exchange and higher performance (Rezapour \& Sattari Ardabili, 2017). Consistently, we argue that some extent emotional intelligence protective against nurses' work outcomes can be in relation with quality of relationship between leaders, nurses, and mediating role of the nurses' psychological empowerment; therefore, the first hypothesis is formed.
$\mathbf{H}_{01}$ : Leader-member exchange mediates the relationship between emotional intelligence, job satisfaction, and emotional exhaustion.

\subsection{Moderating Effects of Self-Efficacy on Job Outcomes}

Self-efficacy is an individual's belief in his or her capacities or abilities to muster the cognitive, motivational, and behavioral resources required to perform in a given situation (Bandura, 1997). It means that self-efficacy refers to the situation-specific nature of competence belief. It's closely related to the relevant variables affecting on the performance of nurses and healthcare centers such as job satisfaction and emotional exhaustion. A sense of self-efficacy had a significant impact on the level of stress and the ways of dealing with difficult situations among nurses (Chegini, Janati, Asghari-Jafarabadi, \& Khosravizadeh, 2019; Liu \& Aungsuroch, 2019) and can help to decrease job stress and less exhaustion (Voitenko, 2020). Furthermore, low self- efficacy and high self-efficacy were strongly correlated to the job stress and job satisfaction, respectively (Manojlovich, 2005; Skaalvik \& Skaalvik, 2010). Researchers found that people with a high level self-efficacy have more confidence in their abilities and therefore like to set up challenging and specific goals which committed to them (Sue-Chan \& Ong, 2002) and more likely to be succeed more in challenging tasks (Luthans, Youssef, \& Avolio, 2007). The leaders' enthusiasm may arouse emotions in their staff through encouraging them to increase their levels of self-efficacy (Ashkanasy \& Dasborough, 2003). This process depends on employees' emotions and leaders relationships with individual employees. On the other hand, there is a relationship among communication competence, self-efficacy, and job satisfaction (Arfara, Tsivos, Samanta, \& Kyriazopoulos, 2017; Park, Jeoung, Lee, \& Sok, 2015). Therefore, it is expected that people who possess high levels of self-efficacy have effective communication skills. Self-efficacy not only can build a better relationship between leader-subordinate, but also it can improve through better relationships with superiors or managers. Self-employment not only has a direct relationship with the job consequences, but also has a significant effect of on the interaction between leader and subordinates and career implications. Therefore, the second hypothesis is formulated.

$\mathbf{H}_{02}$ : Degree of self-efficacy moderates the positive interactive effect of emotional intelligence and leader-member exchange on job satisfaction and emotional exhaustion. 


\subsection{Indirect Effects of Emotional Intelligence on Psychological Empowerment and Employee Work Outcomes}

The recent body of theoretical and empirical research develops linking psychological empowerment to the positive employees' work outcomes such as job satisfaction, organizational commitment, and job performance (Permarupan, Al Mamun, Samy, Saufi, \& Hayat, 2020). As the employees perceive that their work is meaningful and has a significant impact on their skills or competencies which gives them autonomy to make decisions on how to do their work or determine for themselves, they become more able to express their values and true interests through their work experiences (Seibert, Wang, \& Courtright, 2011). This may lead to the higher levels of job satisfaction and greater organizational commitment which provide them such job opportunities. Herzberg, Mausner, and Snyderman (2011) proposed that employees who are more intrinsically motivated than other employees will derive a greater sense of satisfaction from the value of their work and apt to demonstrate a greater effort for successful execution of job duties. Seibert et al. (2011) stated that meta-analysis found that psychological empowerment was related positively to job satisfaction, organizational commitment, and job performance. By considering this combination, the second hypothesis which predicts that psychological empowerment mediates the interactive effect of LMX (Aggarwal, Chand, Jhamb, \& Mittal, 2020) and degree of emotional intelligence on job satisfaction, organizational commitment, and job performance, will positively significant and we have referred to it as a first stage of moderation model in which the path from the independent variable like leader-member exchange to the mediator variable such as psychological empowerment is moderated while this path from the mediator to the dependent variable is not moderated. In terms of the relationship between leader-member exchange and employees' work outcomes or attitudes, it should lead to a conditional indirect effect where the indirect effect of leader-member exchange on employees' work outcomes through psychological empowerment is dependent upon the communication degree which they have. Furthermore, communication degree strengthens the positive relationship between leader-member exchange and psychological empowerment. The higher degree of communication can predict a strong positive inverse relationship between leader-member exchange and employees' work outcomes through psychological empowerment. Therefore, the third hypothesis was formed as follow:

$\mathbf{H}_{03}$ : Psychological empowerment mediates the interactive effect of emotional intelligence and leader-member exchange on job satisfaction and emotional exhaustion.

Figure 1 reflects the development of theoretical framework of study in which the degree of self-efficacy moderates the relationship that leader-member exchange mediates between emotional intelligence and nurses' job satisfaction and emotional exhaustion. On the other side, psychological empowerment also mediates the relationship between leader-member exchange and job outcomes.

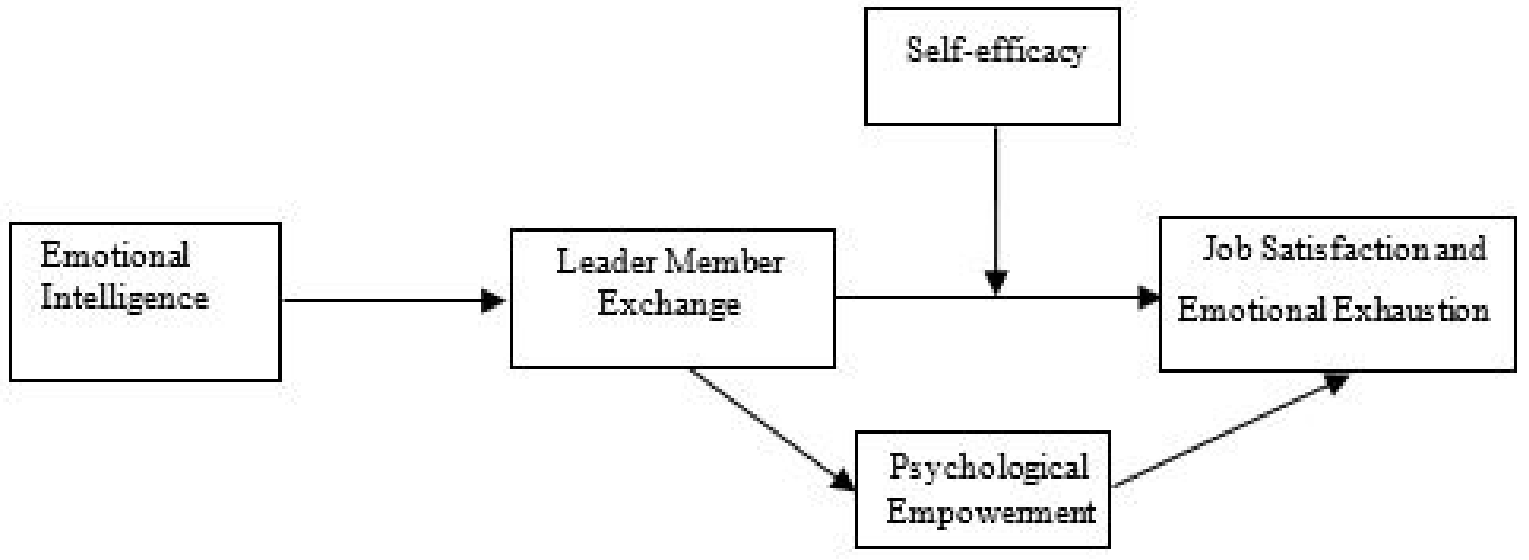

Figure 1: The theoretical framework of study 


\section{Method}

\subsection{Sample and Procedure}

The participants of the study were selected from nurses in three public-sector hospitals in North West of Iran via applying convenience sampling method and random sampling used in each cluster. Only one hundred thirty-eight questionnaires were replied out of 260 ones (response rate $=53.1 \%$ ) and 23 of them were excluded due to incomplete data. All participants were asked to indicate their age, gender $(1=$ male, 2 = female $)$; and the level of education (ranging from $1=$ high school degree to $5=$ postgraduate university degree). The average age of nurses was 33.5 years old $(\mathrm{SD}=4.6)$. Seventy-nine percent of the respondents were female.

\subsection{Measures}

\subsubsection{Emotional Intelligence}

Wong and Law Emotional Intelligence Scale (Wong \& Law, 2002) as a self-report scale was used to measure the respondents' emotional intelligence. It consists of four dimensions which are consistent with Mayer and Salovey's definition of emotional intelligence. These dimensions are self-emotional appraisal (SEA), others' emotional appraisal (OEA), regulation of emotion (ROE), and use of emotion (UOE). This questionnaire consists of 16 items with a 5 point Likert- scale.

\subsubsection{Leader-Member Exchange}

To measure the quality of leader-member exchange, Liden, Wayne, and Stilwell (1993) adaptation of (Scandura \& Graen, 1984) were used. Items were scored on a seven-point rating scale ranging from 1 (strongly disagree) to 7 (strongly agree). It rates the quality of nurses' relationships with their supervisors. Employee-rated leader-member exchange was used because our theorizing specifically has focused more on employees' perceptions of the quality of supervisor-subordinate relationship or high quality of leader-member exchange. A sample items was "My supervisor understands my problems and needs" and "My supervisor would use his or her influence to help me solve problems in my work". The estimated Coefficient alpha was 0.87 .

\subsubsection{Psychological Empowerment}

Psychological empowerment was assessed using Spreitzer's (1995) 12-item scale. It used three items for each of the four dimensions of psychological empowerment, namely meaning, competence, autonomy, and impact. The items such as my job activities are personally meaningful to me, and my impact on what happens in my work team is large refer to these dimensions, respectively. Reliability of questionnaire was reported by using Cronbach's alpha as 0.91. Consistent with those found in previous studies and theories such as Chen and Klimoski (2003) and Zhang and Bartol (2010) which conceptualized and measured psychological empowerment as an overall motivational construct through conducting Confirmatory Factor Analysis (CFA). The results comprised of four sub-dimensions, the fit indices for 4 first-order factors and 1 second-order factor demonstrated goodness of fit $(\chi 2=163.02, p<0.00$, Nonnormed Fit Index (NFI) $=0.80$, Comparative Fit Index $(\mathrm{CFI})=0.84$, The Root Mean Square Error of Approximation $($ RMSEA $)=0.14)$. In this study, the four dimensions were averaged into a single psychological empowerment scale.

\subsubsection{Self-Efficacy}

Perceived self-efficacy was measured by means of general self-efficacy scale (Schwarzer \& Jerusalem, 1995). The measure taps beliefs in one's capability to handle difficult tasks in a variety of other domains. It consists of 10 items that are rated on a 4-point scale with the anchors not at all true and exactly true. An example item is "I can handle whatever comes my way." Higher scores on this measure indicate higher levels of general self-efficacy. Longitudinal studies have reflected variable stability coefficients which ranging from 0.47 to 0.75 (Scholz, Doña, Sud, \& Schwarzer, 2002).

\subsubsection{Emotional Exhaustion}

Professional burnout is a gradual psychological process which is produced due to occupational stress and it is composed of high levels of employees' emotional exhaustion, high depersonalization, and low personal accomplishment levels (Halbesleben \& Buckley, 2004). The most widely used research instrument is Maslach Burnout Inventory - General Survey (MBI-GS) which was used to measure burnout among non-human service workers (Schaufeli \& Taris, 2005). The emotional exhaustion subscale of the MBI-GS was used to measure emotional exhaustion. Its 5 items were rated on a 7-point Likert scale ranging from 0 (never) to 6 (every day).

\subsubsection{Job Satisfaction}

Job satisfaction was measured through five-point Likert scale based on the Quality of Employment Survey. This in- 
strument contains five general measures applicable to any profession including criminal justice jobs (Holt \& Blevins, 2011). High scores represented higher levels of job satisfaction and low scores represented low job satisfaction.

\subsection{Analyses}

\subsubsection{Analytic Approach}

For data assessment, AMOS 20 and SPSS 20 statistical programs were used. Before hypothesis testing, PROCESS was used as computational tool for path analysis (Hayes, 2013). Furthermore, the evaluation of measurement model was done through confirmatory factor analysis (CFA) to consider the analytical distinctiveness of each construct through anticipating the item load on their respective constructs. In order to assess the research model fit, several goodness-of-fit indices as suggested in Structural Equation Modeling (SEM) were applied (Kline, 2015) such as Chisquare statistics divided by degrees of freedom $(\chi 2 / \mathrm{df})$ that recommended to be less than 3 , Relative Fit Index (RFI), Normed Fit Index (NFI), Comparative Fit Index (CFI), Tucker-Lewis Coefficient (TLI); RFI, NFI, CFI and TLI greater than 0.90 is also recommended. Root Mean Square Error of Approximation (RMSEA) as another index is bet- ter to be up to 0.05 and acceptable up to 0.08 . Harman's single factor test (Podsakoff, MacKenzie, Lee, \& Podsakoff, 2003) was used to identify the common method variance of factors because the dependent and independent variables were reported by the same source or individual.

Entering the values of dependent and independent variables in one factor analysis with principal factor axis factoring and varimax rotation, six factors emerged with Eigen values greater than 1 . The outcomes exposed to the highest variance of 29.07 per cent. The results indicated that Common Method Variance (CMV) did not impact on the findings of the study.

In order to avoid errors in data entry, the data was entered twice and comparison was made between two separate data entries (Barchard \& Christensen, 2007). SPSS was used to do missing data imputation and analysis over some of the study variables using the recommended expectation-maximization (EM) algorithm (Schafer \& Graham, 2002). On average, there were 1.52 percent missing values in the study variables ( $\mathrm{SD}=1.75$; Range $=0-6.4$ percent $)$. Little (1988) proposed a chi-square test which indicated that these values were missing completely at random $(\chi 2)$ $\mathrm{df}=6.03, \mathrm{p}=0.00)$. His research showed that the imputation of missing data using the EM algorithm was appropriate. Table 1 presents the summary of descriptive statistics for the variables and their correlations.

Table 1: The Summary of Descriptive Statistics \& Correlations

\begin{tabular}{|c|c|c|c|c|c|c|c|c|}
\hline & M & SD & 1 & 2 & 3 & 4 & 5 & 6 \\
\hline Gender & 1.79 & 0.40 & -- & & & & & \\
\hline Leader Member & 3.20 & 0.69 & 0.06 & -- & & & & \\
\hline Emotional Exhausting & 2.62 & 0.88 & $-0.21 *$ & $-0.31 * *$ & -- & & & \\
\hline Job satisfaction & 2.32 & 0.66 & -0.05 & $0.45^{* *}$ & $-0.54^{* *}$ & -- & & \\
\hline Self-efficacy & 2.87 & 0.55 & -0.05 & $0.37 * *$ & -0.17 & 0.17 & -- & \\
\hline $\begin{array}{l}\text { Psychological Empower- } \\
\text { ment }\end{array}$ & 3.61 & 0.80 & 0.04 & $0.43 * *$ & $-0.20 *$ & 0.17 & $0.68^{*}$ & -- \\
\hline Emotional Intelligence & 2.62 & 0.88 & 0.03 & 0.27 & -0.21 & 0.03 & 0.63 & $0.72^{*}$ \\
\hline \multicolumn{9}{|c|}{ * Correlation is significant at the 0.05 level } \\
\hline
\end{tabular}

\subsubsection{Discriminant Validity of Constructs}

At first, confirmatory factor analysis (CFA) was conducted on variables such as leader-member exchange, psychological empowerment, job satisfaction, job exhaustion, self-efficacy, and emotional intelligence for establishing their Discriminant Validity. This was important because all of these variables were from the same source. For the purpose of the study, two models were selected and then compared. First, a one-factor model was used where the load of all items on one factor for four above mentioned scales was assumed $(\chi 2=1911.71, p<0.00, \mathrm{NNFI}=0.46$, CFI $=0.56$, RMSEA $=0.12$ ). Second, a six-factor model with leader-member exchange, job exhaustion, job satisfaction, self-efficacy, emotional intelligence, and psychological empowerment loaded on separate factors $(\chi 2=1884.00, \mathrm{p}$ $<0.00, \mathrm{NNFI}=0.67, \mathrm{CFI}=0.67, \mathrm{RMSEA}=0.09)$.

The first model demonstrated poor fit of the model to the data while the second model showed better fit indices to the data in which psychological empowerment 
and self-efficacy were modeled as second order factors. After the purification processes, all the standardized factor loadings exceeded $0.05(\mathrm{p}<0.01)$ suggest the evidence of convergent validity. Discriminant validity was checked by comparing the proportion of average variance extracted (AVE) for each construct to the square of the correlation coefficients. Table 2 demonstrates the overall reliability of the constructs and factor loadings of the indicators. The proportion of variance extracted in each construct exceeded the respective squared correlation coefficients as an evidence of discriminant validity. Table 3 demonstrates the result of test for discriminant validity.

Table 2: Overall Reliability of the Constructs \& Factor Loadings of Indicators

\begin{tabular}{|c|c|c|}
\hline Constructs & Items & $\begin{array}{l}\text { F a c t o r } \\
\text { Loadings }\end{array}$ \\
\hline Self-Efficacy & I can always manage to solve difficult problems if I try hard enough. & 0.53 \\
\hline \multirow{9}{*}{$\begin{array}{l}\text { NFI }=0.70 \\
\mathrm{IFI}=0.77 \\
\mathrm{TLI}=0.62 \\
\mathrm{CFI}=0.75 \\
\text { RMSEA }=0.13 \\
\text { Chi- Square }=112.48 \\
\text { Cronbach }=0.84\end{array}$} & If someone opposes me, I can find the means and ways to get what I want. & n.a \\
\hline & It is easy for me to stick to my aims and accomplish my goals. & 0.58 \\
\hline & I am confident that I could deal efficiently with unexpected events. & 0.58 \\
\hline & Thanks to my resourcefulness, I know how to handle unforeseen situations. & 0.64 \\
\hline & I can solve most problems if I invest the necessary effort. & 0.61 \\
\hline & I can remain calm when facing difficulties because I can rely on my coping abilities. & 0.58 \\
\hline & When I am confronted with a problem, I can usually find several solutions. & 0.53 \\
\hline & If I am in trouble, I can usually think of a solution. & 0.62 \\
\hline & I can usually handle whatever comes my way. & 0.59 \\
\hline \multirow{4}{*}{$\begin{array}{l}\text { Psychological Em- } \\
\text { powerment } \\
\text { NFI }=0.80 \mathrm{IFI}=0.85 \\
\mathrm{TLI}=0.76 \\
\mathrm{CFI}=0.84 \\
\mathrm{RMSEA}=0.14 \\
\text { Chi- Square }=163.02 \\
\text { Cronbach }=0.91\end{array}$} & Competence & 0.96 \\
\hline & Self determination & 0.97 \\
\hline & Meaning & 0.85 \\
\hline & Impact & 0.89 \\
\hline \multirow[t]{5}{*}{ Job Satisfaction } & All in all, how you how satisfied are you with your job? & 0.69 \\
\hline & $\begin{array}{l}\text { Knowing what you know now, if you had to decide all over again whether to take } \\
\text { the job you now have, what would you decide }\end{array}$ & 0.84 \\
\hline & $\begin{array}{l}\text { In general, how well would you say your job measures up to the sort of job you } \\
\text { wanted when you took it? }\end{array}$ & 0.85 \\
\hline & $\begin{array}{l}\text { If a good friend of yours told you he (or she) was interested in working in a job like } \\
\text { yours for your employer, what would you tell him (or her)? }\end{array}$ & 0.75 \\
\hline & If you were free to go into any of job you wanted, what would your choice be? & n.a \\
\hline \multirow{2}{*}{$\begin{array}{l}\text { Leader-Member } \\
\text { Exchange }\end{array}$} & Do you know where you stand with your leader ... & n.a \\
\hline & How well does your leader understand your job problems and needs & n.a \\
\hline \multirow{5}{*}{$\begin{array}{l}\text { NFI }=0.88 \\
\mathrm{IFI}=0.92 \\
\mathrm{TLI}=0.84 \\
\mathrm{CFI}=0.92 \\
\mathrm{RMSEA}=0.13 \\
\text { Chi }- \text { Square }=41.37 \\
\text { Cronbach }=0.87\end{array}$} & How well does your leader recognize your potential & 0.74 \\
\hline & $\begin{array}{l}\text { What are the chances your leader would use his/her power to help you solve prob- } \\
\text { lems in your work }\end{array}$ & 0.78 \\
\hline & $\begin{array}{l}\text { Regardless of the amount of formal authority your employee has, what are the } \\
\text { chances that he/she would 'bail you out' at his/her expense }\end{array}$ & 0.80 \\
\hline & $\begin{array}{l}\text { I Have enough confidence in my leader that I would defend and justify his or her } \\
\text { decision if he or she were not present to do so. }\end{array}$ & 0.74 \\
\hline & How would you characterize your working relationship with your leader & 0.71 \\
\hline
\end{tabular}


Table 2: Overall Reliability of the Constructs \& Factor Loadings of Indicators (continues)

\begin{tabular}{|c|c|c|}
\hline \multirow{5}{*}{$\begin{array}{l}\text { Job Exhaustion } \\
\text { NFI }=0.93 \\
\text { IFI }=0.95 \\
\text { TLI }=0.85 \\
\text { CFI }=0.95 \\
\text { RMSEA }=0.13 \\
\text { Chi }- \text { Square }=15.14 \\
\text { Cronbach }=0.83\end{array}$} & I feel burned out from my work & 0.74 \\
\hline & I feel emotionally drained from my work. & 0.87 \\
\hline & I feel fatigued when I get up in the morning and have to face another day on the job. & 0.87 \\
\hline & Working with people all day is really a strain for me & 0.69 \\
\hline & I feel frustrated by my job & 0.93 \\
\hline \multirow{4}{*}{$\begin{array}{l}\begin{array}{l}\text { Emotional Intelli- } \\
\text { gence }\end{array} \\
\text { NFI }=0.83 \\
\text { IFI }=0.91 \\
\text { TLI }=0.87 \\
\text { CFI }=0.90 \\
\text { RMSEA }=0.09 \\
\text { Chi- Square }=196.97 \\
\text { Cronbach }=0.91 \\
\end{array}$} & Self-emotion appraisal (SEA) & 0.81 \\
\hline & Others' emotion appraisal (OEA) & 0.84 \\
\hline & Use of emotion (UOE) & 0.56 \\
\hline & Regulation of emotion (ROE) & 0.86 \\
\hline
\end{tabular}

Table 3: Discriminant Validity

\begin{tabular}{|c|c|c|c|c|c|c|c|c|c|c|}
\hline & CR & AVE & MSV & ASV & $\begin{array}{c}\text { Empower- } \\
\text { ment }\end{array}$ & $\begin{array}{c}\text { Job } \\
\text { Satisfac- } \\
\text { tion }\end{array}$ & $\begin{array}{c}\text { Exhaus- } \\
\text { tion }\end{array}$ & $\begin{array}{c}\text { Leader_- } \\
\text { Member }\end{array}$ & $\begin{array}{c}\text { Self_Effi- } \\
\text { cacy }\end{array}$ & Emotional \\
\hline Empowerment & 0.94 & 0.59 & 0.47 & 0.40 & 0.77 & & & & & \\
\hline Job Satisfaction & 0.99 & 0.97 & 0.85 & 0.40 & 0.59 & 0.98 & & & & \\
\hline Exhaustion & 0.96 & 0.86 & 0.85 & 0.38 & -0.58 & -0.92 & 0.93 & & & \\
\hline Leader-Member & 0.95 & 0.82 & 0.79 & 0.41 & 0.69 & 0.89 & -0.83 & 0.90 & & \\
\hline Self -Efficacy & 0.81 & 0.52 & 0.38 & 0.16 & 0.61 & 0.12 & -0.14 & & 0.72 & \\
\hline Emotional & 0.90 & 0.52 & 0.46 & 0.17 & 0.67 & 0.03 & -0.09 & 0.18 & 0.59 & 0.72 \\
\hline
\end{tabular}

\section{Results}

\subsection{Hypotheses Testing}

Table 4 demonstrates the results for the first and second hypotheses. These hypotheses predicted the conditional indirect effects of emotional intelligence through leader-member exchange on emotional exhaustion and job satisfaction. The mediating effects were examined by procedures discussed in Hayes (2013) and using the PROCESS Macro (Model 4). The relationship between emotional intelligence and job outcomes including exhaustion and job satisfaction were tested at different leader-member exchange levels in this study. Outputs along with 95 percent bias-corrected bootstrap confidence intervals based on
5000 bootstrap samples are shown in Table 2. The direct effect of emotional intelligence on emotional exhaustion was significantly negative $(B=-0.206, t=-2.00,95 \% C I$ $[-0.41,-0.00], p=0.04)$. The standardized indirect effect of emotional intelligence on emotional exhaustion through leader-member exchange was significant $(\mathrm{B}=-0.10, \mathrm{SE}=$ $0.05,95 \% \mathrm{CI}=[-0.23,-0.02], \mathrm{t}=-2.07, \mathrm{p}=0.00)$. After including leader-member exchange as a mediator of the relationship, emotional intelligence still had a significant direct effect on emotional exhaustion $(\mathrm{B}=-0.20, \mathrm{t}=-2.00)$ and this path reduces the magnitude of this effect. Table 4 shows that the indirect effect of emotional intelligence on job exhaustion through leader-member exchange is consistently negative. It decreased as the values of leader-member exchange relationship increased. Approximate 95 percent biased-corrected bootstrap confidence intervals 
for the conditional indirect effect is less than zero for values of leader-member exchange. Hence, leader-member exchange completely mediates emotional intelligence influence on job exhaustion $(\mathrm{B}=-0.08,95 \% \mathrm{CI}=[-0.17$,$0.02], \mathrm{SE}=0.03)$. Moreover, there were significant positive relationship between leader-member exchange with both occupational outcomes including job exhaustion and job satisfaction were significant $(\mathrm{B}=0.47, \mathrm{SE}=0.07, \mathrm{t}=6.29$, $\mathrm{p}=0.00$ ) while there was an inverse relationship between leader-member exchange and burnout $(\mathrm{B}=-0.360, \mathrm{SE}=$ $0.14, \mathrm{t}=-2.56, \mathrm{p}=0.05)$.

In second phase of the first hypothesis, the impact of emotional intelligence on job satisfaction was investigated as a first step to demonstrate the existence of an indirect effect of emotional intelligence on job satisfaction via leader-member exchange as a mediator $(\mathrm{B}=-0.05, \mathrm{p}=$ $0.45,95 \% \mathrm{CI}(-0.18,0.08))$. The results revealed that there was not a significant relationship between emotional intelligence and job satisfaction. Therefore, leader-member exchange could not consider as a mediator between emotional intelligence and job satisfaction, but it can be entered as a single block into the model. There was a significant interaction between job satisfaction and single block and this interaction was shown in the form of EI*LMX that was the result of indirect effect $(\mathrm{B}=0.08, \mathrm{SE}=0.03,95 \% \mathrm{CI}[0.02$, $0.17], Z=2.29)$. Therefore, leader-member exchange mediated the relationship between emotional intelligence and burnout. Table 4 presents the leader-member mediating effects of emotional intelligence on job satisfaction and emotional exhaustion.

Table 4: LMX Mediating Effects of EI on Job Satisfaction \& Emotional Exhaustion

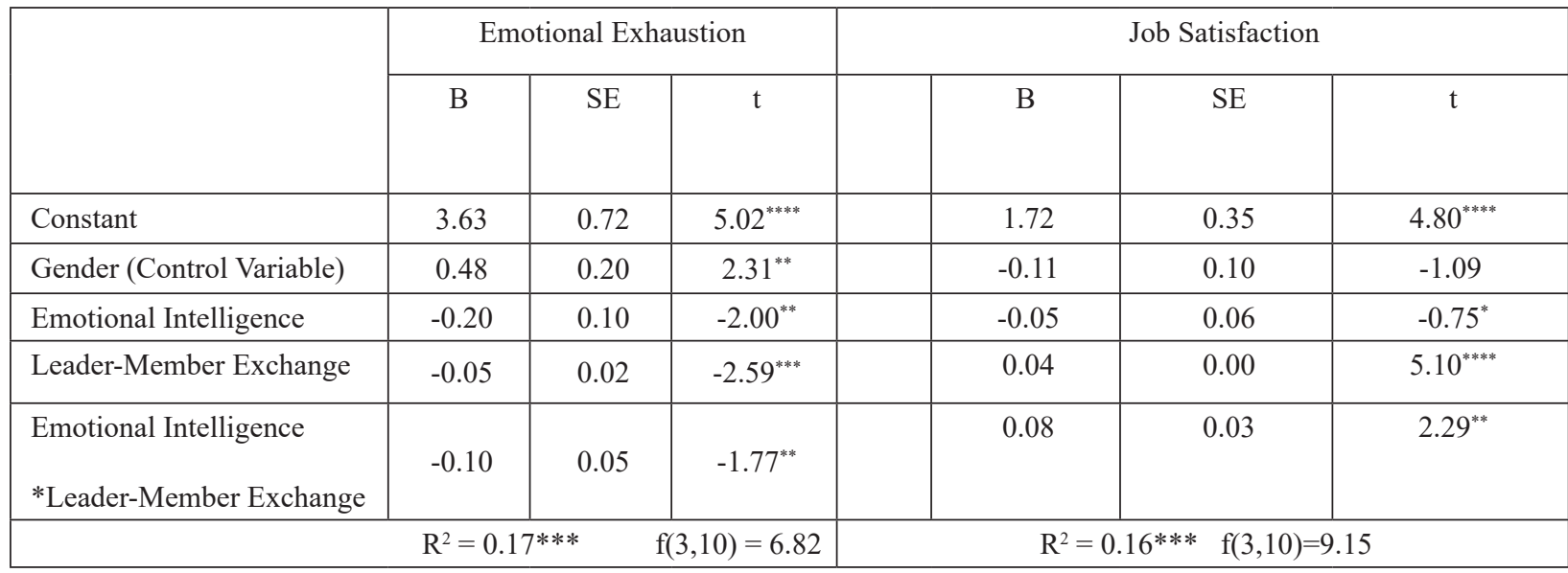

$* \mathrm{P}<0.10, * * \mathrm{P}<0.05, * * * \mathrm{P}<0.01, * * * * \mathrm{P}<0.001$

To determine whether if leader-member exchange and psychological empowerment could mediate the relationship between emotional intelligence and job outcomes including job satisfaction and exhaustion respectively, Hayes PROCESS $\backslash$ process macro was conducted to analyze the mediation effect and then add psychological aspect to the model (Model 6) (Hayes, 2013). The results revealed that psychological empowerment as a dependent variable could significantly be predicted by emotional intelligence $(\mathrm{B}=0.73, \mathrm{SE}=0.08, \mathrm{t}=9.19,95 \% \mathrm{CI}=[0.57$, $0.89], \mathrm{p}=0.00)$ and leader-member exchange $(\mathrm{B}=0.04$, $\mathrm{SE}=0.08, \mathrm{t}=4.09,95 \% \mathrm{CI}=[0.02,0.07], \mathrm{p}=0.00, \mathrm{R} 2$ $=0.60, F(3,103)=78.80)$. The results indicated that only the mediating role of leader-member exchange can be considered significant in the relationship between emotional intelligence (EI- > LMX- > EX) and psychological empowerment, and psychological empowerment did not act significantly as moderator in this relationship (EI-
$>$ LMX-> PS- $>$ EX) $(\mathrm{B}=-0.10, \mathrm{SE}=0.06,95 \% \mathrm{CI}=$ $[-0.26,-0.01])$. Table 5 demonstrated the mediating effects of member-leader exchange and psychological empowerment on the relationship between emotional intelligence and job outcomes.

Table 6 demonstrates the results of third hypothesis in which job outcomes were significantly affected by emotional intelligence through mediating role of leader-member exchange, while in the second hypothesis self-efficacy acted as moderator. According to the Model 14 (Hayes, 2013), the relationship between emotional intelligence and job satisfaction was significant only when leader-member exchange had mediating role $(\mathrm{B}=-0.27,95 \% \mathrm{CI}=[-0.47$, $-0.07], \mathrm{p}=0.00$ ).

Table 7 states that emotional intelligence had indirect positive effect on job satisfaction through applying the mediating effect of leader-member exchange. As its values decreased, the values of self-efficacy increased. 
Table 5: The Mediating Effects of Member-Leader Exchange \& Psychological Empowerment on the Relationship between Emotional Intelligence \& Job Outcomes

\begin{tabular}{|c|c|c|c|c|c|c|}
\hline & \multicolumn{3}{|c|}{ Emotional Exhaustion } & \multicolumn{3}{|c|}{ Job Satisfaction } \\
\hline & $\mathrm{B}$ & $\mathrm{SE}$ & $\mathrm{t}$ & $\mathrm{B}$ & SE & $\mathrm{t}$ \\
\hline Constant & 3.63 & 0.72 & $5.12^{* * *}$ & 1.72 & 0.36 & $4.77^{* * *}$ \\
\hline Gender & 0.48 & 0.20 & $2.30^{*}$ & -0.11 & 0.10 & -1.06 \\
\hline Emotional Intelligence & -0.22 & 0.15 & -1.46 & -0.07 & 0.08 & -0.90 \\
\hline Leader-Member Exchange & -0.05 & 0.02 & $-2.44^{*}$ & 0.04 & 0.01 & $3.79^{* * *}$ \\
\hline Psychological Empowerment & 0.01 & 0.16 & 0.11 & 0.03 & 0.09 & 0.39 \\
\hline $\begin{array}{l}\text { Emotional Intelligence } * \text { Leader- } \\
\text { Member Exchange }\end{array}$ & -0.10 & 0.05 & $(-0.24,-0.02)$ & 0.08 & 0.03 & $(0.02,0.17)$ \\
\hline $\begin{array}{l}\text { Emotional Intelligence } \\
\text { *Leader-Member Exchange } \\
\text { *Psychological Empowerment }\end{array}$ & 0.00 & 0.01 & $(-0.02,0.04)$ & 0.00 & 0.01 & $(-0.01,0.02)$ \\
\hline $\begin{array}{l}\text { Emotional Intelligence } \\
\text { *Psychology Empowerment }\end{array}$ & 0.01 & 0.11 & $(-0.20,0.24)$ & 0.02 & 0.06 & $(-0.11,0.15)$ \\
\hline \multicolumn{4}{|c|}{$\mathrm{R}^{2}=0.17^{* * * *}$} & \multicolumn{3}{|c|}{$\mathrm{R}^{2}=0.17^{* * *} \quad \mathrm{f}(4,10)=7.94$} \\
\hline
\end{tabular}

$* \mathrm{P}<0.10, * * \mathrm{P}<0.05, * * * \mathrm{P}<0.01, * * * * \mathrm{P}<0.001$

Table 6: Mediating-Moderating Effect of Leader-Member Exchange \& Self-Efficacy

\begin{tabular}{|l|c|c|c|c|c|c|}
\hline \multirow{2}{*}{} & \multicolumn{2}{|c|}{ Emotional Exhaustion } & \multicolumn{3}{c|}{ Job Satisfaction } \\
\cline { 2 - 7 } & $\mathrm{B}$ & $\mathrm{SE}$ & $\mathrm{t}$ & $\mathrm{B}$ & $\mathrm{S}$ & $\mathrm{t}$ \\
\hline Constant & 2.78 & 0.73 & $3.80^{* * *}$ & 3.02 & 0.36 & $8.31^{* * *}$ \\
\hline Gender & 0.47 & 0.20 & $2.30^{*}$ & -0.11 & 0.10 & -1.14 \\
\hline Leader-Member Exchange & -0.05 & 0.01 & $-3.27^{* *}$ & 0.03 & 0.00 & $4.18^{* * *}$ \\
\hline Emotional Intelligence & -0.28 & 0.14 & $-1.91^{*}$ & -0.13 & 0.07 & $-1.87^{*}$ \\
\hline SE & 0.16 & 0.21 & 0.75 & 0.18 & 0.11 & 1.72 \\
\hline Emotional Intelligence*Leader-member & -0.27 & 0.29 & -0.91 & -0.27 & 0.10 \\
\hline Exchange*Self-Efficacy & & & & $\mathrm{R}^{2}=0.22^{* * *} \mathrm{f}(5,101)=9.95$ \\
\hline $\mathrm{R}^{2}=0.19^{* * *} \mathrm{f}(5,10)=5.07$ & & & \\
\hline
\end{tabular}

Table 7: Conditional Indirect Effects of Emotional Intelligence on Job Satisfaction through Leader-Member Exchange at Values of Self Efficacy as Moderator

\begin{tabular}{|c|c|c|c|c|c|}
\hline \multirow{2}{*}{ Mediators } & \multicolumn{2}{|c|}{} & \multicolumn{2}{|c|}{$\begin{array}{c}\text { Bias Corrected Bootstrap 95\% Confi- } \\
\text { dence Interval }\end{array}$} \\
\cline { 2 - 5 } & Self-Efficacy & Indirect Effect & Boot SE & Lower & 0.03 \\
\hline $\begin{array}{c}\text { Leader-Member Ex- } \\
\text { change }\end{array}$ & -0.53 & 0.11 & 0.04 & 0.02 & 0.14 \\
\hline $\begin{array}{c}\text { Leader-Member Ex- } \\
\text { change }\end{array}$ & 0.00 & 0.06 & 0.03 & -.011 & 0.10 \\
\hline $\begin{array}{c}\text { Leader-Member Ex- } \\
\text { change }\end{array}$ & 0.53 & 0.02 & 0.02 & 0.10 \\
\hline
\end{tabular}

Notes: Values for self-efficacy (moderator) are the mean and plus/minus one standard deviation (SD) from the mean. 
A $95 \%$ of bias-corrected bootstrap confidence of interval for the conditional indirect effect was entirely above zero for low-to-medium levels of self-efficacy. Hence, leader-member exchange partially mediated the effect of emotional intelligence on job satisfaction, except when self-efficacy values were large. Finally, index of moderated mediation described by (Hayes, 2013) was estimated $(-0.07)$ which was significant $(95 \% \mathrm{CI}=[-.187,-.016])$ as zero fell outside the conditional indirect effects.

\section{Discussion}

This study investigated the roles that leaders play in mediating emotional intelligence effects on job satisfaction and emotional exhaustion with regard to psychological empowerment and self- efficacy of nurses. Given the demonstrated challenges associated with nurses' work outcomes (Permarupan et al., 2020), the key role of exchange between leader and member is surprising. The effects of self-efficacy (MacPhee, Skelton-Green, Bouthillette, \& Suryaprakash, 2012), emotional intelligence (Mohebbi, Coombe, \& Kirkpatrick, 2017) and psychological empowerment (Laschinger et al., 2007; MacPhee et al., 2012) on work outcomes are approved except for how these different factors effect on work outcomes with regard to each other. Consistent with previous researches that has examined the interaction between leader-member exchange and work outcomes (Loi, Chan, \& Lam, 2014; Rezapour \& Sattari Ardabili, 2017), this study also referred to the importance of leadership in promoting positive work outcomes in hospital. The findings showed that participants' leader-member exchange mediates the effect of emotional intelligence on job outcomes. Leader-member exchange is considered as an important boundary condition for understanding the relationship between emotional intelligence and psychological empowerment as well as self-efficacy and job outcomes. This resulted in a mediated effect in which the indirect effect of emotional intelligence on emotional exhaustion through leader-member exchanges was more strongly negative especially at higher levels of leader-member exchange. In spite of existing a weak negative relationship between emotional intelligence and job satisfaction, the direct effect of leader-member exchange on job satisfaction was high enough in a way that through the mediating role of leader-member exchange the relationship of emotional intelligence could become significantly positive. Previous studies (Gorgens-Ekermans \& Brand, 2012; Voitenko, 2020) investigated the impact of emotional intelligence on emotional exhaustion and burnout which can increase through mediating role of leader-member exchange. Actually, the quality of subordinate-superordinate relationship can reduce or prevent the employees' emotional exhaustion. Those employees, who have a higher degree of emotional intelligence, experience less emotional exhaustion. Furthermore, the strength of this relationship can enhance as the superior-subordinate relationship improve. Unlike most of previous studies which showed that high levels of emotional intelligence lead to higher job satisfaction (Benson, Ploeg, \& Brown, 2010 ), the results of this study revealed that there was an inverse relationship between the level of nurses' emotional intelligence and decreasing their job satisfaction (through mediating leader-member exchange). In previous studies, the superior-subordinate relationship was not investigated that is why this relationship was not much significant (Kafetsios, 2007). It can be argued that the nurses who had high levels of emotional intelligence had less willingness to stay in their current jobs due to their high communicating skills with other private clinics and hospitals and therefore were less satisfied with their jobs (Wu \& Norman, 2006). In the same conditions, therefore, different results or job outcomes could be expected based on emotional intelligence. A qualified relationship with superior could positively change the results. It means that it was not only reduces the level of burnout, but also it also was the main cause of job satisfaction among employees. So, the employees with high levels of emotional intelligence could have a good relationship with their supervisors and therefore their satisfaction level of their job could be improved. These results of study indicated that only using the nurses who had higher levels of emotional intelligence could not guarantee the enhancement hospital services' quality and efficiency and the quality of their relationship with their superiors was an influential factor. Laschinger et al. (2007) investigated that building a good relationship between nurses and their supervisors could cause job satisfaction without considering the nurses' emotional intelligence. The effect of this relationship should properly be determined through psychological empowerment of nurses. Unlike the study of Lyu, Ji, Zheng, Yu, and Fan (2019), the psychological empowerment of the nurses did not have a direct effect on job satisfaction and burnout and it was in line with the study of Yip (2004) who stated that the perception of empowerment differed in western and eastern societies because western culture supported espoused values in democratic culture and society. These conflicting research results may be due to the lack of consideration to the leader-member relationship in these studies. Thus, it can be concluded that psychological empowerment did not effect on the job outputs independently. The results also revealed that self- efficacy and leader-member exchange did not act as an independent mediator in the relationship of emotional intelligence and burnout. It can be deduced that self-efficacy of physical dimension of an occupation as an influential factor can effect on burnout. Physical and emotional dimensions of an occupation and job environment cannot regulate with self-efficacy and work-related variables (Maslach \& Jackson, 1981). Emotional intelligence also cannot regulate them alone, but just can influence on 
the quality of relationship with superiors. Herzberg (1966) stated that emotional intelligence was considered as one of the motivational factors and should be considered different from other health factors. The condition is different regarding the job satisfaction because it is related to the human physical processes and working conditions (Cropanzano \& Mitchell, 2005). Therefore, the mediating role of self-efficacy has a significant effect on the relationship between leader-member exchange and job satisfaction. It also acts as a compliment for the physical dimension of job satisfaction which investigates the effect of leader-member exchange and emotional intelligence on job satisfaction.

\section{Conclusion}

The results of this study showed that the research on different occupations can bring different results especially for occupations that are stressful and have excessive workload (McVicar, 2003). It is not necessary to seek an overhasty generalization of the results of previous studies in nursing job, but categorizing the different dimensions of theories seems to be necessary. Due to the novelty of this study which investigated the mediating and moderating effects of leader-member exchange, self-efficacy, and psychological empowerment on relationship between emotional intelligence and work attitudes, the findings failed to support any potential positive role of psychological empowerment as a mediator between emotional intelligence and leader-member exchange as well as job satisfaction and emotional exhaustion. In other words, contrary to expectations, neither emotional psychology nor self-efficacy can predict emotional exhaustion. Based on the obtained results, although self-efficacy affected on the relationship between emotional intelligence, leader-member exchange, and job satisfaction, it was surprisingly inefficient about the same relationship with the influence of emotional exhaustion. The importance of leadership training can never be underestimated. Effective leadership skills, especially communication skills for the nurses, seem to be necessary for the board of supervisors to develop supervisors' leadership skills and qualities, improve employees' job satisfaction, and decrease employees' emotional exhaustion. Investigating the relationships among nurses' self-efficacy beliefs and their perceptions may be helpful to improve the nurses' performance. Future research needs to examine the ways in which emotional intelligence effects may be moderated by more non-personal factors such as social support, job identity, and especially organizational climate which cover the emotions in organizations. Like previous studies, this study also suffers from some limitations. First, the statistical population of the study was restricted to nurses' perceptions of the quality of their leader-member exchange relationship, self-efficacy, and emotional empowerment; therefore, the data generally obtained from just a single source. Therefore, the findings of this study cannot necessarily be generalized to all occupations. Second, supervisors and nurses ratings of leader-member exchange might not appear on the same line (Hill, Kang, \& Seo, 2014). Third, though efforts should be made to reduce the effects of biases especially at interpreting the results. To validate the conclusions, it is better to seek out the samples from multiple sources and occupations which need less communication skills such as virtual jobs and employees on production lines.

\section{Literature}

Aggarwal, A., Chand, P. K., Jhamb, D., \& Mittal, A. (2020). Leader-member exchange, work engagement, and psychological withdrawal behavior: the mediating role of psychological empowerment. Frontiers in Psychology, 11:423. https://doi.org/10.3389/ fpsyg.2020.00423

Al-Maaitah, N. A. (2019). The Spatial Variation in Women Empowerment in Jordan: A Cross Country Comparative Overview Management and Business Research Quarterly, 11, 20-34. https://doi.org/10.32038/ mbrq.2019.11.03

Arfara, C., Tsivos, G., Samanta, I., \& Kyriazopoulos, P. (2017). The Integration of Information Technology to Facilitate HRM Functions: The Case of the Health Care Sector (Biomedicine Group). Management and Business Research Quarterly, 3, 38. https://doi. org/10.32038/mbrq.2017.03.03

Ashkanasy, N. M., \& Dasborough, M. T. (2003). Emotional Awareness and Emotional Intelligence in Leadership Teaching. Journal of Education for Business, 79(1), 18-22. http://doi. org/10.1080/08832320309599082

Bandura, A. (1997). Self-efficacy : the exercise of control. New York: Freeman.

Barchard, K. A., \& Christensen, M. M. (2007). Dimensionality and higher-order factor structure of self-reported emotional intelligence. Personality and Individual Differences, 42(6), 971-985. http://dx.doi. org/10.1016/j.paid.2006.09.007

Benson, G., Ploeg, J., \& Brown, B. (2010). A cross-sectional study of emotional intelligence in baccalaureate nursing students. Nurse Educ Today, 30(1), 49-53. http://doi.org/10.1016/j.nedt.2009.06.006

Chegini, Z., Janati, A., Asghari-Jafarabadi, M., \& Khosravizadeh, O. (2019). Organizational commitment, job satisfaction, organizational justice and self-efficacy among nurses. Nursing Practice Today. http://dx.doi. org/10.18502/npt.v6i2.913

Chen, G., \& Klimoski, R. J. (2003). The Impact of Expectations on Newcomer Performance in Teams as Mediated by Work Characteristics, Social Exchanges, and Empowerment. The Academy of Management Journal, 46(5), 591-607. https://doi.org/10.2307/30040651 
Cropanzano, R., \& Mitchell, M. S. (2005). Social exchange theory: An interdisciplinary review. Journal of management, 31(6), 874-900. https://doi. org/10.1177\%2F0149206305279602

Evans, D., \& Allen, H. (2002). Emotional intelligence: its role in training. Nurs Times, 98(27), 41-42. https:// doi:10.1007/978-0-387-88370-0 8

Gorgens-Ekermans, G., \& Brand, T. (2012). Emotional intelligence as a moderator in the stress-burnout relationship: a questionnaire study on nurses. J Clin Nurs, 21(15-16), 2275-2285. http://doi.org/10.1111/j.13652702.2012.04171.x

Halbesleben, J. R., \& Buckley, M. R. (2004). Burnout in organizational life. Journal of management, 30(6), 859-879.

Hayes, A. F. (2013). Introduction to mediation, moderation, and conditional process analysis: A regression-based approach: Guilford Press. https://doi. org/10.1111/jedm.12050.

Herzberg, F., Mausner, B., \& Snyderman, B. B. (2011). The motivation to work (Vol. 1): Transaction publishers. ISBN:1412815541, 9781412815543

Hill, N. S., Kang, J. H., \& Seo, M.-G. (2014). The interactive effect of leader-member exchange and electronic communication on employee psychological empowerment and work outcomes. The Leadership Quarterly, 25(4), 772-783. https://doi.org/10.1016/j. leaqua.2014.04.006

Holt, T. J., \& Blevins, K. R. (2011). Examining job stress and satisfaction among digital forensic examiners. Journal of Contemporary Criminal Justice, 27(2), 230-250. https://doi. org/10.1177\%2F1043986211405899

Kafetsios, K. (2007). Work-family conflict and its relationship with job satisfaction and psychological distress: The role of affect at work and gender. Hellenic Journal of Psychology, 4(1), 15-35. Retrived from: https://pseve.org/wp-content/uploads/2018/05/ Volume04_Issue1_Kafetsios.pdf

Kline, R. B. (2015). Principles and practice of structural equation modeling: Guilford publications. ISBN: 9781462523344.

Laschinger, H. K. S., Purdy, N., \& Almost, J. (2007). The impact of leader-member exchange quality, empowerment, and core self-evaluation on nurse manager's job satisfaction. Journal of Nursing Administration, 37(5), 221-229. https://doi.org/10.1097/01. NNA.0000269746.63007.08

Liden, R. C., Wayne, S. J., \& Stilwell, D. (1993). A longitudinal study on the early development of leader-member exchanges. Journal of Applied Psychology, 78(4), 662. https://psycnet.apa.org/doi/10.1037/00219010.78.4.662

Little, R. J. (1988). A test of missing completely at random for multivariate data with missing values. Journal of the American Statistical Association, 83(404), 1198-1202. http://doi.org/
$10.1080 / 01621459.1988 .10478722$

Liu, Y., \& Aungsuroch, Y. (2019). Work stress, perceived social support, self-efficacy and burnout among Chinese registered nurses. J Nurs Manag, 27(7), 14451453. https://doi.org/10.1111/jonm.12828

Loi, R., Chan, K. W., \& Lam, L. W. (2014). Leader-member exchange, organizational identification, and job satisfaction: A social identity perspective. Journal of Occupational and Organizational Psychology, 87(1), 42-61. https://doi.org/10.1111/joop.12028

Luthans, F., Youssef, C. M., \& Avolio, B. J. (2007). Psychological capital: Developing the human competitive edge: Oxford University Press Oxford. http://doi.org/ 10.1093/acprof:oso/9780195187526.001.0001

Lyu, D., Ji, L., Zheng, Q., Yu, B., \& Fan, Y. (2019). Abusive supervision and turnover intention: Mediating effects of psychological empowerment of nurses. International Journal of Nursing Sciences, 6(2), 198203. https://doi.org/10.1016/j.ijnss.2018.12.005

MacPhee, M., Skelton-Green, J., Bouthillette, F., \& Suryaprakash, N. (2012). An empowerment framework for nursing leadership development: supporting evidence. J Adv Nurs, 68(1), 159-169. https://doi. org/10.1111/j.1365-2648.2011.05746.x

Manojlovich, M. (2005). Promoting Nurses‘ Self-efficacy: A Leadership Strategy to Improve Practice. Journal of Nursing Administration, 35(5), 271-278. https:// doi.org/10.1097/00005110-200505000-00011

Maslach, C., \& Jackson, S. E. (1981). The measurement of experienced burnout. Journal of organizational behavior, 2(2), 99-113.

McVicar, A. (2003). Workplace stress in nursing: a literature review. J Adv Nurs, 44(6), 633-642. http://doi. org/10.1046/j.0309-2402.2003.02853.x

Mohebbi, H., Coombe, C., \& Kirkpatrick, R. (2017). Emotional Intelligence: Continuing Controversies and Unresolved Issues Language Teaching Research Quarterly, 4, 12-24. http://doi.org/10.32038/ ltrq.2017.04.02

Park, M. S., Jeoung, Y., Lee, H. K., \& Sok, S. R. (2015). Relationships among communication competence, self-efficacy, and job satisfaction in Korean nurses working in the emergency medical center setting. J Nurs Res, 23(2), 101-108. http://doi.org/10.1097/ jnr.0000000000000059

Permarupan, P. Y., Al Mamun, A., Samy, N. K., Saufi, R. A., \& Hayat, N. (2020). Predicting Nurses Burnout through Quality of Work Life and Psychological Empowerment: A Study Towards Sustainable Healthcare Services in Malaysia. Sustainability, 12(1), 388. https://doi.org/10.3390/su12010388

Podsakoff, P. M., MacKenzie, S. B., Lee, J. Y., \& Podsakoff, N. P. (2003). Common method biases in behavioral research: a critical review of the literature and recommended remedies. J Appl Psychol, 88(5), 879-903. http://doi.org/10.1037/0021-9010.88.5.879 
Rezapour, F., \& Sattari Ardabili, F. (2017). Leader-member exchange and its relationship with career adaptability and job satisfaction among employees in public sector. International Journal of Organizational Leadership, 6, 425-433. http://dx.doi.org/10.33844/ ijol.2017.60405

Scandura, T. A., \& Graen, G. B. (1984). Moderating effects of initial leader-member exchange status on the effects of a leadership intervention. Journal of Applied Psychology, 69(3), 428. https://psycnet.apa. org/doi/10.1037/0021-9010.69.3.428

Schafer, J., \& Graham, J. (2002). Missing data: Our view of the state of the art. Psychological Methods, 7(2), 147-177. https://doi.org/10.1037/1082-989X.7.2.147

Schaufeli, W. B., \& Taris, T. W. (2005). The conceptualization and measurement of burnout: Common ground and worlds apart The views expressed in Work \& Stress Commentaries are those of the author (s), and do not necessarily represent those of any other person or organization, or of the journal. Work \& Stress, 19(3), 256-262. https://doi. org/10.1080/02678370500385913

Scholz, U., Doña, B. G., Sud, S., \& Schwarzer, R. (2002). Is general self-efficacy a universal construct? Psychometric findings from 25 countries. European Journal of Psychological Assessment, 18(3), 242. https://psycnet.apa.org/doi/10.1027//1015-5759.18.3.242

Schwarzer, R., \& Jerusalem, M. (1995). Generalized self-efficacy scale Weinman, J., Wright, S., Johnston, M. Measures in health psychology: A user's portfolio. Causal and control beliefs, 35-37. Retrived from http://userpage.fu-berlin.de/health/engscal.htm

Seibert, S. E., Wang, G., \& Courtright, S. H. (2011). Antecedents and consequences of psychological and team empowerment in organizations: a meta-analytic review. J Appl Psychol, 96(5), 981-1003. http://doi. org/10.1037/a0022676

Skaalvik, E. M., \& Skaalvik, S. (2010). Teacher self-efficacy and teacher burnout: A study of relations. Teaching and Teacher Education, 26(4), 1059-1069. https:// doi.org/10.1016/j.tate.2009.11.001

Spreitzer, G. M. (1995). Psychological empowerment in the workplace: Dimensions, measurement, and validation. Academy of Management Journal, 38(5), 1442-1465. https://doi.org/10.2307/256865

Sue-Chan, C., \& Ong, M. (2002). Goal assignment and performance: Assessing the mediating roles of goal commitment and self-efficacy and the moderating role of power distance. Organizational Behavior and Human Decision Processes, 89(2), 1140-1161. https:// doi.org/10.1016/S0749-5978(02)00017-1

Voitenko, E. (2020). Emotional burnout as a result of professional stress in the work of managers. Journal of Behavior Studies in Organizations, 3, 5-12. http:// dx.doi.org/10.32038/JBSO.2020.03.02

Wen, J., Huang, S., \& Hou, P. (2019). Emotional intelligence, emotional labor, perceived organizational support, and job satisfaction: A moderated mediation model. International Journal of Hospitality Management, 81, 120-130. https://doi.org/10.1016/j. ijhm.2019.01.009

White, D., \& Grayson, S. (2019). The importance of emotional intelligence in nursing care. J Comp Nurs Res Care, 4, 152. https://doi.org/10.33790/jcnrc1100152.

Wong, C.-S., \& Law, K. S. (2002). The effects of leader and follower emotional intelligence on performance and attitude: An exploratory study. The Leadership Quarterly, 13(3), 243-274. https://doi.org/10.1016/ S1048-9843(02)00099-1

Wu, L., \& Norman, I. (2006). An investigation of job satisfaction, organizational commitment and role conflict and ambiguity in a sample of Chinese undergraduate nursing students. Nurse Educ Today, 26(4), 304-314. https://doi.org/10.1016/j.nedt.2005.10.011

Yip, K.-s. (2004). The empowerment model: A critical reflection of empowerment in Chinese culture. Social Work, 49(3), 479-487. Retrieved July 10, 2020, from www.jstor.org/stable/23721085

Zhang, X., \& Bartol, K. M. (2010). Linking empowering leadership and employee creativity: The influence of psychological empowerment, intrinsic motivation, and creative process engagement. Academy of Management Journal, 53(1), 107-128. Retrieved July 10, 2020, from www.jstor.org/stable/25684309

Farzad Sattari Ardabili is Assistant Professor in the Department of Management, Islamic Azad University, Ardabil Branch, Iran. He has worked as executive manager in a consultant company and as a research head at University. His practical experience in research and in educational organizations had persuaded him to study on organizational behaviour. He focused in conducting research in leadership and organizational behaviour. Currently he is working on wisdom and its relationships with career adaptability, ambidextrous behaviour and self-efficacy. Because of his educational background in operational research, he is particularly interested in mixed method research in different multicultural organizations. He also served as conference organizer in more than 10 international conferences over period of 2015-2019. 